\title{
Seasonal growth of Codium bursa, a slow-growing Mediterranean macroalga: in situ experimental evidence of nutrient limitation
}

\author{
Beatriz Vidondo, Carlos M. Duarte \\ Centro de Estudios Avanzados de Blanes, CSIC, Camí de Santa Bárbara s/n, E-17300 Blanes, Girona, Spain
}

\begin{abstract}
The seasonal growth of Codium bursa J. Agardh was examined in relation to ambient and internal nutrient concentrations to elucidate whether the low tissue nutrient concentrations observed are an intrinsic feature of this species or reflect nutrient-limited growth. Growth rates were rather low (mean \pm SE: $2.2 \pm 0.4 \times 10^{-3} \mathrm{~d}^{-1}$; doubling time $=1.24 \pm 0.1 \mathrm{yr}$ ), and were significantly correlated to seasonal changes in ambient and internal nutrient concentrations, suggesting nutrient, probably $\mathrm{P}$, limitation. This suggestion is supported by the rather high atomic tissue C/P ratios (1712), compared to $\mathrm{C} / \mathrm{N}$ ratios (31.8) observed in summer. This was confirmed by experimentally injecting nutrients into the internal lumen of the plants in situ, which resulted in a doubling of growth rate, photosynthetic efficiency, and a reduction in light compensation irradiance $\left(39.6\right.$ and $29.9 \mu \mathrm{mol}$ photons $\mathrm{m}^{-2} \mathrm{~s}^{-1}$ in control and fertilised specimens, respectively). These results provide, along with the strong correlation between growth rate and ambient and internal phosphorus concentrations, clear evidence of a tight nutrient (likely phosphorus), rather than light or temperature, control of $C$. bursa growth rates. Hence, even inherently slow-growing organisms in the oligotrophic Mediterranean may be resource limited.
\end{abstract}

KEY WORDS: Slow-growing macroalga $\cdot$ Growth $\cdot$ Nutrient limitation

\section{INTRODUCTION}

Slow-growing macroalgae are important components of oligotrophic coastal environments (Duarte 1995). They dominate there because their slow growth rate results in low nutrient requirements, and because, by being thick and long-lived, they minimise losses (Duarte 1995). Because of their growth strategy, slowgrowing macroalgae are paradigms of 'stress-tolerant' plants (Grime 1974). Stress-tolerant plants are considered to be relatively independent of resource availability, with their production being limited by their own intrinsic growth, rather than resource supply (e.g. Chapin 1988). Conversely, slow-growing macroalgae have thick thalli and, therefore, low surface-to-volume ratios, which should impose a low nutrient uptake capacity (Hein et al. 1995). As a consequence, slowgrowing macroalgae show low nutrient concentrations (Duarte 1995), and may experience nutrient limitation, despite their low nutrient demand.

Codium bursa J. Agardh., a balloon-like Mediterranean macroalga, has been recently shown to rank amongst the slowest-growing plants yet studied (Geertz-Hansen et al. 1994). C. bursa supports extremely low photosynthetic rates and grows very slowly, but develops considerable biomass and reaches large sizes (>20 cm in diameter), indicating that they must experience few losses (Geertz-Hansen et al. 1994). Yet, we observed unusually low phosphorus concentrations in the tissues of $C$. bursa (average $\mathrm{C} / \mathrm{P}=$ $1472 \pm 64$; cf. Geertz-Hansen et al. 1994), suggesting that it may be phosphorus limited despite its low growth and nutrient demands. Phosphorus has been shown to limit the growth of phytoplankton (Estrada 1979, Krom et al. 1991), and seagrasses (Pérez et al. 1991, 1994) in the Mediterranean, and it may well be that this also applies to the slowest growing plants there (i.e. C. bursa). Demonstration of nutrient limitation in $C$. bursa would challenge the notion that intrinsically slow-growing, stress-tolerant plants are relatively independent of resource availability (Grime 1974, Chapin 1988).

Examination of the seasonal growth pattern of this species in relation to ambient nutrient concentrations 
could help ascertain whether the low nutrient concentration observed is an intrinsic feature of this species. Correlations between seasonal growth and ambient nutrient concentrations would suggest nutrient limitation, which must then be confirmed by experimental evidence. Here we follow this approach to test the importance of nutrients for the growth of Codium bursa, one of the slowest-growing macroalgal species. We first examine seasonal growth patterns, and their relation to ambient and internal nutrient concentrations. The extent of nutrient limitation of the growth and photosynthesis of $C$. bursa was tested in summer, the time of greatest nutrient deficiency in Mediterranean plants (Ballesteros 1989, Pérez et al. 1991, 1994, Delgado et al. 1994, Alcoverro et al. 1995). The peculiar form of this algae, a hollow sphere, was used to examine its response to enrichment in situ, which was achieved by injecting nutrients into the internal lumen of the plants.

\section{METHODS}

Seasonal growth study. The study was conducted between February 1993 and May 1994 in Cala Jonquet, a protected, shallow cove in the NW Mediterranean $\left(42^{\circ} 18.26^{\prime} \mathrm{N}, 3^{\circ} 18.11^{\prime}\right.$ E) where a dense Codium bursa stand grows on a rocky platform between 5 and $10 \mathrm{~m}$ depth. Growth of C. bursa was measured at 30 to $50 \mathrm{~d}$ intervals, using a plant marking technique by tagging at least 30 undisturbed $C$. bursa specimens ranging in size from 1 to $16 \mathrm{~cm}$ with a numbered float attached to the thick $C$. bursa by a plastic cable tied around their base or to a nail next to the smaller $(<4 \mathrm{~cm})$ specimens. The loss of organisms or tags over the study was compensated by tagging new individuals to maintain a sample size greater than 30 individuals. On each visit, the diameter of tagged plants was measured in situ to the nearest $0.2 \mathrm{~mm}$, using a calliper. Diameter measurements were converted into algal dry weight using a regression equation built with a large $(\sim 200)$ sample size (Geertz-Hansen et al. 1994). Specific growth rates $\left(\mu, \mathrm{d}^{-1}\right)$ were calculated from the increase in algal size over each measurement period using the equation:

$$
\mu=\frac{\left(\frac{W_{t}-W_{0}}{W_{0}}\right)}{t}
$$

where $t$ is the duration (d) of the measurement period, and $W_{l}$ and $W_{0}$ are the final and initial dry weights of the specimens, respectively.

At each visit, 10 Codium bursa specimens, ranging in diameter between 1 and $20 \mathrm{~cm}$, were collected for nutrient analysis. A $20 \mathrm{ml}$ sample of the water filling the lumen of 2 mid-size $(5$ to $8 \mathrm{~cm}$ ) and 2 large (15 to $20 \mathrm{~cm}$ ) specimens, and duplicate samples of ambient water, were withdrawn with sterile syringes for analysis of dissolved inorganic nutrients, and stored frozen after adding 2 drops of a chloroform solution. The tissues of 4 small, 2 mid-size, and 4 large specimens were cleaned of epiphytes, the internal water drained off, and dried $\left(24 \mathrm{~h}\right.$ at $\left.80^{\circ} \mathrm{C}\right)$ to be analysed for tissue $\mathrm{C}, \mathrm{N}$, and $\mathrm{P}$ concentrations

In situ enrichment experiment. The nutrient addition experiment was conducted between August and October 1993, following the detection of an increase in tissue $\mathrm{C} / \mathrm{P}$ ratio and a decline in growth rate. The nutrient addition experiment was conducted in situ by adding nutrients directly to the water in the lumen of the plant, benefiting from the peculiar form of this species. Using SCUBA we injected $10 \mathrm{ml}$ of a nutrientrich medium containing $105 \mu \mathrm{mol}$ of inorganic $N$ (as nitrate), $4.3 \mu \mathrm{mol}$ of inorganic $\mathrm{P}$ (as phosphate), as well as metals, and vitamins in proportions similar to $f / 2$ medium (cf. Guillard \& Ryther 1962), into the lumen of each of 40 specimens with relatively uniform sizes ( 7 to $14 \mathrm{~cm}$ diameter). A second needle inserted in the opposite side of the algae allowed evacuation of the excess water, thereby preventing any pressure stress, but involving some loss of added nutrients. We, therefore, evaluated the enrichment applied by sampling. using a syringe, the internal water of 5 additional organisms for nutrient analysis following injection of the nutrient solution. These samples indicated an initial nutrient concentration in the water of the internal lumen of fertilised specimens of $522.5 \pm 93.3 \mu \mathrm{M}$ of $\mathrm{NO}_{3}, 1.08 \pm 0.04 \mu \mathrm{M}$ of $\mathrm{NH}_{4}$, and $13 \pm 2.5 \mu \mathrm{M}$ of $\mathrm{PO}_{4}$, compared to $1.63 \pm 0.50 \mu \mathrm{M}$ of $\mathrm{NO}_{3}, 0.82 \pm 0.43 \mu \mathrm{M}$ of $\mathrm{NH}_{4}$, and $0.03 \pm 0.00 \mu \mathrm{M}$ of $\mathrm{PO}_{4}$ in that of control specimens. Nutrient addition, therefore, involved a 2 to 3 order-of-magnitude increase in nutrient concentrations, but did not alter the N/P ratio of the water in the internal lumen of the algae. A second nutrient addition was performed $10 \mathrm{~d}$ later to compensate for losses, since experiments with tritiated water indicate the residence time of the water in the internal lumen of Codium bursa to be short (about 1 to $2 \mathrm{~d}_{\text {; }} \mathrm{O}$. GeertzHansen unpubl.).

Each of the individuals fertilised was subsequently tagged, as described above, to measure growth $50 \mathrm{~d}$ following the nutrient addition, ensuring sufficient time for a measurable growth response in this slowgrowing plant. The growth of unenriched algae tagged as part of the seasonal growth study was used as control. In addition to the growth response (which must be moderate, provided the intrinsic slow growth of these organisms), we measured their photosynthetic rates as a shorter-term indicator of their response to nutrient additions. The photosynthetic rates were measured 10 and $50 \mathrm{~d}$ following nutrient enrichment of 5 fertilised and 5 control individuals. These organisms were trans- 
ported to the laboratory in refrigerated seawater and used to determine photosynthesis versus irradiance (P-I) curves (0 to $500 \mu \mathrm{mol}$ photons $\mathrm{m}^{-2} \mathrm{~s}^{-1}$ ), and to measure chlorophyll a ( $\mathrm{chl}$ a) and nutrient $(\mathrm{C}, \mathrm{N}$, and $\mathrm{P}$ ) concentrations in their tissues.

The specimens collected for photosynthetic measurements were carefully cleaned of epiphytes and placed in wide-mouth, clear glass bottles. Photosynthetic activity was measured through changes in dissolved oxygen concentration, following the recommendations of Littler (1979), Littler \& Arnold (1980) and Kemp et al. (1990), particularly in regard to incubation time, mixing, and sample size (fresh weight relative to bottle volume). The plant material was fitted into $140 \mathrm{ml}$ Winkler bottles, filled with filtered $(0.45 \mu \mathrm{m})$ seawater using a siphon to prevent bubbles and reduce variance in the oxygen concentration among replicates, and incubated at $20^{\circ} \mathrm{C}$, in a MK X Incubator Shaker. Stirring was provided by continuous orbital shaking. Incubation time ranged between 45 min and $4 \mathrm{~h}$, scaled to the rate of oxygen change to ensure accurate estimates of oxygen production in the light and consumption in the dark while avoiding bubble formation and oversaturation. The changes in dissolved oxygen upon incubation at irradiances increasing from darkness to $500 \mu \mathrm{mol}$ photons $\mathrm{m}^{-2} \mathrm{~s}^{-1}$ were measured using an oxygen electrode and meter (Orbisphere 2607 model, sensor 2112 with a built-in stirrer). We used 4 reference bottles (i.e. without plant tissue) incubated at the same light intensities and during the same time period. Illumination was provided by cool-white fluorescent tubes placed above the bottles, and the photon fluency rate was measured with a LI-COR datalogger fitted with a spherical LI-COR sensor.

The P-I curves obtained were used to calculate the photosynthetic efficiency [ $\left(\mathrm{mg} \mathrm{O} \mathrm{O}_{2} \mathrm{~g}\right.$ dry $\mathrm{wt}^{-1} \mathrm{~h}^{-1}$ ) ( $\mu \mathrm{mol}$ photons $\left.\mathrm{m}^{-2} \mathrm{~s}^{-1}\right)^{-1}$ ] which represents the initial increment in oxygen evolution per unit light increase (cf. Kirk 1983), calculated, using linear regression, as the initial slope of the P-I curve (e.g. Lederman \& Tett 1981); dark respiration rate $\left(\mathrm{mg} \mathrm{O}_{2} \mathrm{~g}_{\text {dry }} \mathrm{wt}^{-1} \mathrm{~h}^{-1}\right)$, calculated as the intercept on the ordinate of the regression equation used to calculate photosynthetic efficiency (Lederman \& Tett 1981); the light compensation point ( $\mu$ mol photons $\mathrm{m}^{-2} \mathrm{~s}^{-1}$ ), the irradiance at which photosynthesis and respiration are balanced, calculated as the intercept on the abscissa of the regression equation; and the maximum photosynthetic rate observed within the irradiance range assayed $\left(\mathrm{mg} \mathrm{O} \mathrm{O}_{2} \mathrm{~g}\right.$ dry $w^{-1} \mathrm{~h}^{-1}$ ).

Tissue carbon and nitrogen concentrations were determined for duplicate subsamples ( $4 \mathrm{mg}$ dry wt each), using a Carlo-Erba CHN analyser, while phosphorus concentrations were determined colorimetrically in duplicate subsamples ( $8 \mathrm{mg}$ dry wt each) following wet acid digestion (Koroleff 1983). Coefficients of variation of the duplicate analysis were $1 \%$ for $\mathrm{C}$ and $\mathrm{N}$, and $6 \%$ for P. Nutrient concentrations (nitrate, nitrite, ammonia and phosphate) of the enclosed and ambient water were analysed colorimetrically on an autoanalyzer following Strickland \& Parsons (1972)

Daily incident irradiance was obtained from a station $21 \mathrm{~km}$ south of the study site (St. Pere Pescador, Girona; collected by Mas Badía Experimental Research Station, Generalitat de Catalunya). Surface water temperature was measured at $0.5 \mathrm{~m}$ depth weekly at a site (L'Estartit, Girona; J. Pascual unpubl.) located $27.5 \mathrm{~km}$ south of the study site. We averaged water temperature by month and calculated the cumulative irradiance received during marking periods.

The relationship between seasonal growth rate and growth conditions (incoming irradiance, water temperature, and ambient nutrient concentrations) was examined using cross correlation analysis to allow for lagged growth responses. Differences in growth of fertilised versus control plants were tested using a 1-way ANOVA (Sokal \& Rohlf 1981).

\section{RESULTS AND DISCUSSION}

\section{Seasonal plant nutrient status and growth}

The irradiance at the water surface ranged from $1721 \mathrm{E} \mathrm{m}^{-2} \mathrm{mo}^{-1}$ in May 1993 to $292 \mathrm{E} \mathrm{m}^{-2} \mathrm{mo}^{-1}$ in November 1993, with maximum irradiance at the surface being about $2000 \mu \mathrm{mol}$ photons $\mathrm{m}^{-2} \mathrm{~s}^{-1}$, which corresponds to 1200 and $730 \mu \mathrm{mol}$ photons $\mathrm{m}^{-2} \mathrm{~s}^{-1}$ at 5 and $10 \mathrm{~m}$ depth, respectively. Surface water temperature showed a minimum of $12.3^{\circ} \mathrm{C}$ in February 1993, and a maximum of $22.3^{\circ} \mathrm{C}$ in August 1993 (Fig. 1). Minimum phosphate concentrations in ambient waters were observed in August 1993 (0.006 $\mu \mathrm{M}$ ) and May 1994 $(0.03 \mu \mathrm{M})$ while the highest concentration $(0.85 \mu \mathrm{M})$ was observed at the beginning of the experiment (March 1993; Fig. 1). Dissolved inorganic nitrogen (DIN) showed a smooth temporal pattern with a maximum of $4.14 \mu \mathrm{M}$ in November 1993 (Fig. 1), with nitrate and ammonium accounting, on average, for $42.01 \%$ and $53.71 \%$ of DIN, respectively.

Nutrient concentrations in the water enclosed within large Codium bursa individuals followed a pattern parallel to that of ambient nutrient concentrations $\left(\mathrm{r}=0.76\right.$ and $\mathrm{r}=0.73, \mathrm{p}<0.005$, for $\mathrm{PO}_{4}$ and $\mathrm{NO}_{3}$, respectively; Fig. 1). Yet, DIN concentrations in the internal water largely exceeded (by about 10 fold) ambient concentrations, except from July to October, when they were similar (Fig. 1). In contrast, phosphate concentrations in the internal water were substantially lower than ambient concentrations, 

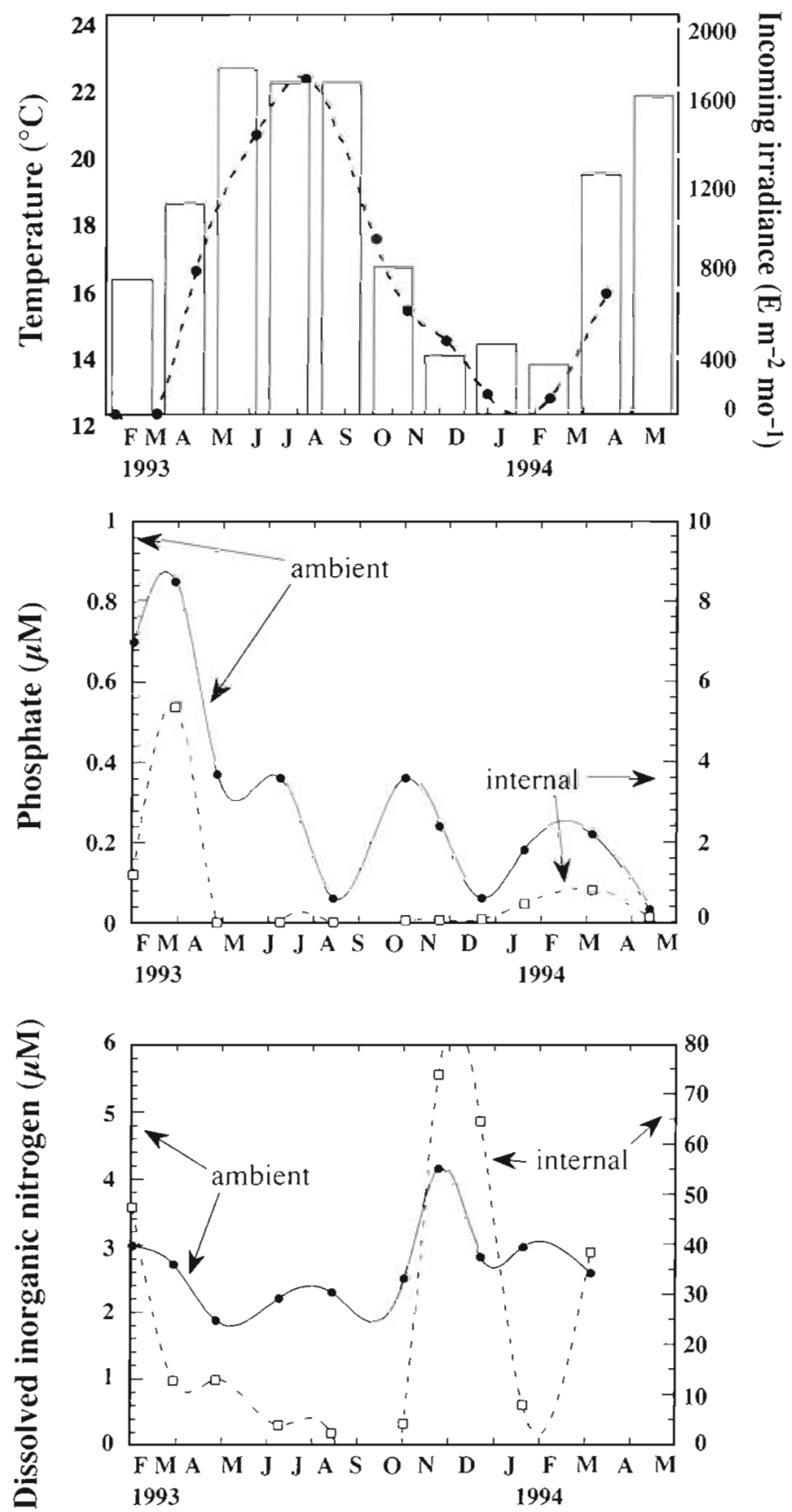

Fig. 1. Temporal variation of incoming irradiance (upper panel, bars), water temperature (upper panel, broken line), and phosphate (middle panel) and dissolved inorganic nitrogen (lower panel) concentrations in ambient and internal (i.e. within the lumen of 15 to $20 \mathrm{~cm}$ Codium bursa specimens) water during the study period

except in winter when internal concentrations exceeded ambient ones (Fig. 1). These results indicate that the water in the internal lumen may represent an important reservoir for $N$, but not for $P$, and points to a greater demand for $\mathrm{P}$, relative to $\mathrm{N}$, by the macroalga.
Tissue nutrient concentrations were very low $10.0318 \pm 0.0065$ and $0.76 \pm 0.17 \%$ dry wt for $P$ and $N$, respectively), as reported before (GeertzHansen et al. 1994), and showed a clear seasonal pattern, with $\mathrm{C} / \mathrm{P}$ and $\mathrm{C} / \mathrm{N}$ atomic ratios increasing in summer, both in large and small specimens (Fig. 2). Seasonal changes in tissue concentrations were correlated with those in ambient and internal waters, both for tissue C/P ( $\mathrm{r}=-0.72$ and -0.57 for ambient and internal water, respectively) and $\mathrm{C} / \mathrm{N}$ atomic ratios $(\mathrm{r}=-0.73$ and -0.64 for ambient and internal water, respectively). The tissue $\mathrm{C} / \mathrm{P}$ ratios observed in summer were very high $(\mathrm{C} / \mathrm{P}=$ 1712), while $\mathrm{C} / \mathrm{N}$ ratios were only moderately high ( $\mathrm{C} / \mathrm{N}=31.8)$, indicative of a greater phosphorus, compared to nitrogen, deficiency in summer.

Codium bursa grew very slowly (mean $\pm \mathrm{SE}$ $\left.2.257 \pm 0.452 \times 10^{-3} \mathrm{~d}^{-1}\right)$, indicative of rather long doubling times $(1.24 \pm 0.152 \mathrm{yr}$ ), but still. shorter than those reported for some crustose red algae (Paine et al. 1979). The maximum specific growth rate was observed in May-June 1993, and a sec-
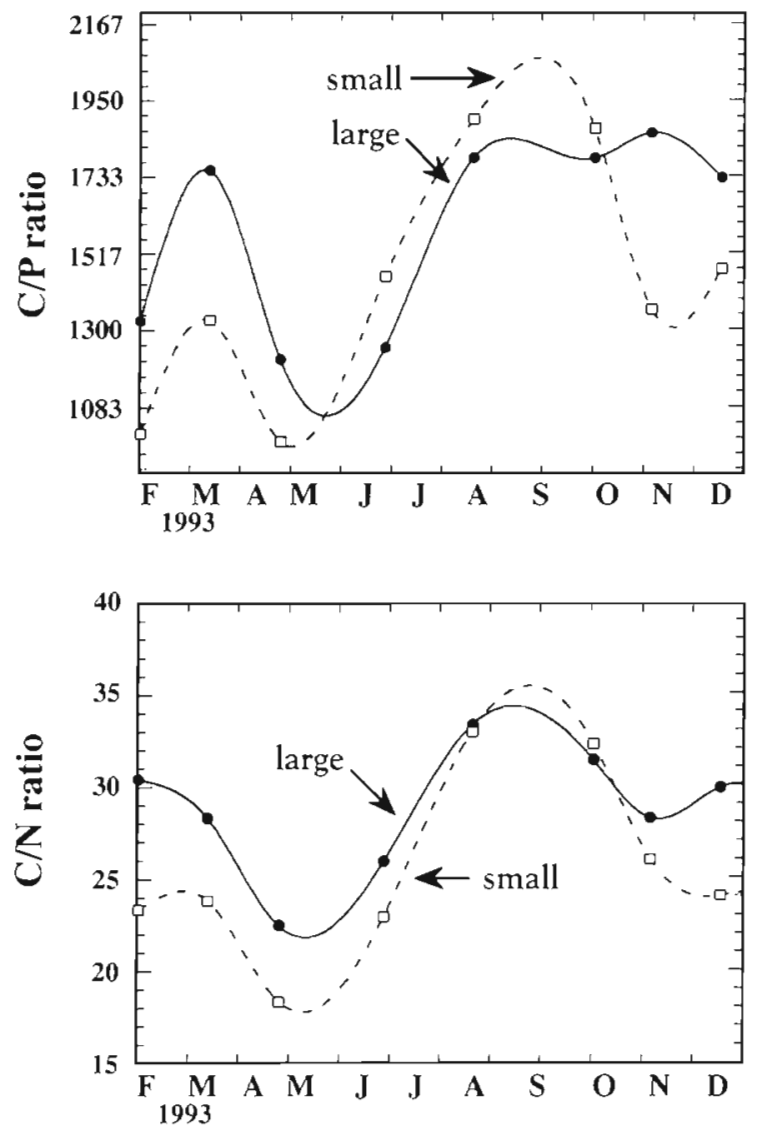

Fig. 2. Codium bursa. Seasonal variation in tissue C/P and $\mathrm{C} / \mathrm{N}$ atomic ratio for large $(15$ to $20 \mathrm{~cm}$ diameter) and small $(<5 \mathrm{~cm})$ specimens 


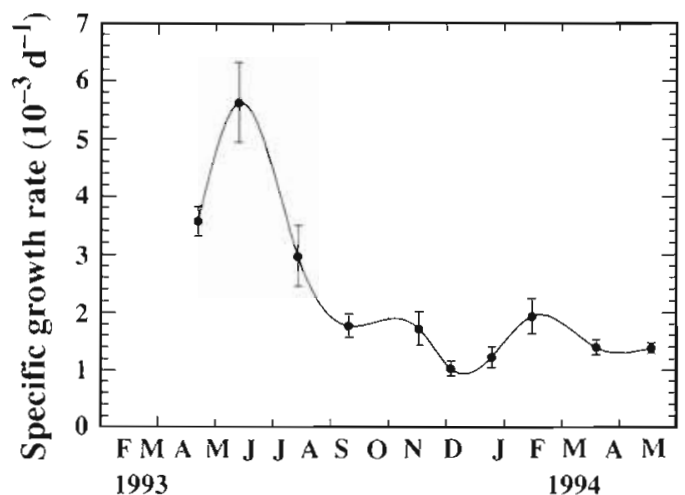

Fig. 3. Codium bursa. Average ( $\pm \mathrm{SE}$ ) specific growth rate during the study period

ondary maximum was observed in January 1994 (Fig. 3). Hence, growth rate did not appear to follow any clear seasonal pattern, and was independent of irradiance or temperature $(\mathrm{r}=0.12, \mathrm{p}>0.05$ and $\mathrm{r}=0.071$, $p>0.05$, respectively). Instead, specific growth rates were closely correlated with ambient $(\mathrm{r}=0.64, \mathrm{p}<$ 0.025 ) and internal ( $r=0.83, p<0.0005)$ phosphate concentrations (Fig. 1). The correlation between growth rate and dissolved inorganic nitrogen was weaker and even negative $(\mathrm{r}=-0.57, \mathrm{p}<0.05)$ for ambient concentration, and non-significant $(\mathrm{r}=$ $-0.47, p>0.05$ ) for internal concentration. In addition, the specific growth rate was closely correlated with the $\mathrm{C} / \mathrm{P}$ ratio of the algal tissues $(r=-0.71, p<0.025)$, but not with $\mathrm{C} / \mathrm{N}$ ratio $(\mathrm{r}=-0.32, \mathrm{p}>0.05)$. These results all point to a dominant role of phosphorus availability, rather than light or temperature, in controlling the specific growth rate of $C$. bursa. Accordingly, the absence of a clear seasonal pattern in $C$. bursa growth rate should derive from the great interannual variability in the seasonal pattern of phosphate concentrations in the NW Mediterranean littoral (J. Cebrián, C. M. Duarte \& J. Pascual unpubl.).

\section{Response to in situ nutrient enrichment}

In situ nutrient additions to the water in the internal lumen of the algae resulted in a significant (ANOVA; $F=5.2, \mathrm{p}<0.02$ ) growth enhancement, specific growth rates increasing by $>100 \%$ in response to nutrient enrichment (Fig, 4). Tissue nutrient concentrations did not change significantly ( $t$-test, $\mathrm{p}>0.4$ for both $\mathrm{P}$ and $\mathrm{N}$ ) in response to nutrient additions. This is, however, expected, provided the long turnover rate of the organism, which implies that only a small fraction (about $12.3 \%$ ) of the tissues had been produced over the $50 \mathrm{~d}$ experimental period. This growth response was paralleled by a similarly high (2-fold and 3-fold increase in August and October, respectively) increase in the photosynthetic efficiency of the organisms, and a significant decline in the respiration rate, as well as a reduction in chl a concentration, particularly in October (Fig. 4). The reduction in chl a concentration in response to nutrient enrichment is difficult to explain, but is consistent with previous observations for phytoplankton (e.g. Wehr 1989). At any rate, this reduction probably has no measurable influence on light acquisition by Codium bursa, whose chl a concentration is too high for efficient light absorption (cf. Geertz-Hansen et al. 1994). These results provide, along with the strong correlation between growth rate and ambient and internal phosphorus concentrations, clear evidence of a tight nutrient (likely phosphorus) control of $C$, bursa growth rates, and extend the range of nutrient-limited phototrophs in the Mediterranean
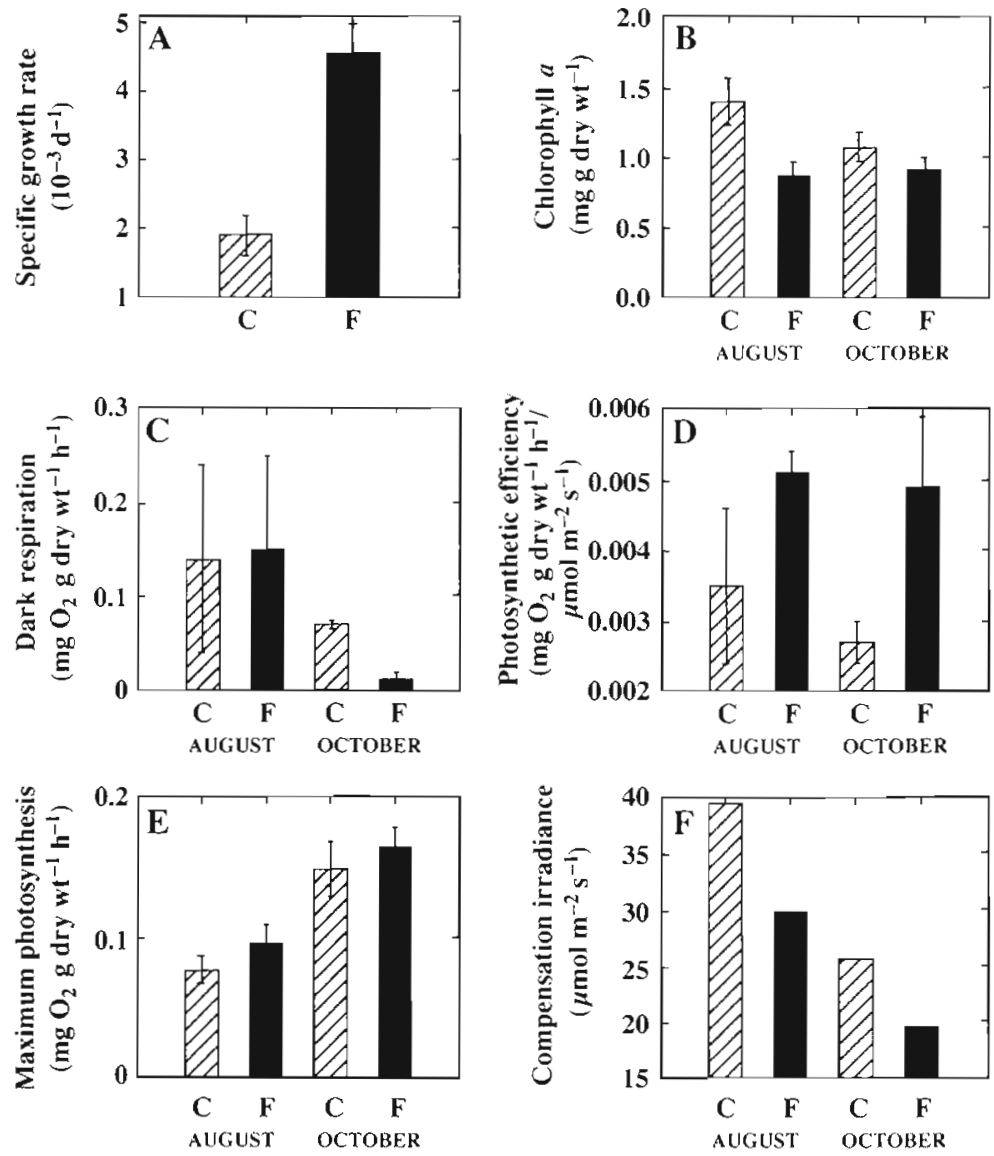

Fig. 4. Codium bursa. Response to in situ nutrient additions 10 (August) and $50 \mathrm{~d}$ (October) following nutrient enrichment. Bars represent average ( \pm SE) for control (C) and fertilised (F) specimens 
from phytoplankton (Estrada 1979, Krom et al. 1991), and seagrasses (Pérez et al. 1991, 1994), to the slowestgrowing macroalgae.

There is abundant evidence of nutrient limitation of macroalgal growth rates (Mann et al. 1980, Valiela 1984, Ramus 1992), most of them derived from laboratory, or mesocosm experiments. The evidence of nutrientlimited Codium bursa growth provided here is particularly important, because of the inherently slow growth of this species and the fact that the experimental evidence was derived in situ, making use of the form of $C$. bursa. Consideration of this peculiar growth form predicts intrinsically low growth rates, derived from the very low photosynthetic rates associated to the spherical shape and thickness of its tissues (Geertz-Hansen et al. 1994), which could also suggest a light-dependence of growth rates. Yet, consideration of the low surface to volume ratio of $C$. bursa also predicts very low nutrient uptake rates (Hein et al. 1995). That $C$. bursa growth, and even photosynthetic rates, are controlled by nutrient supply demonstrates that the constraints the geometry of $C$. bursa imposes on its capacity to acquire nutrients overrule those imposed on the efficiency of light capture. Moreover, the control of $C$. bursa growth by nutrients was so severe as to uncouple it from the seasonal changes in light and temperature that determine the seasonal pattern of most Mediterranean macrophytes (Ballesteros 1991, Pérez \& Romero 1992, Terrados \& Ros 1992, Alcoverro et al. 1995).

The finding that an organism with exceedingly low intrinsic growth rates may have these reduced even further by nutrient limitation and still develop high biomasses (Geertz-Hansen et al. 1994) appears paradoxical. The only possible explanation for this paradox relies on the achievement of similarly reduced loss rates as the basis of the growth strategy of Codium bursa. Such reduced losses may be readily inferred from our results, which indicate that the life span of $C$. bursa exceeds 16 yr (i.e. the time to reach the largest size observed) in our study site. The results presented provide clear evidence that even inherently slowgrowing organisms may be resource limited. Increasing resource availability at the ecosystem scale, however, would not be conducive to a better performance of $C$. bursa, for it will also favour growth of other, faster-growing plants (macroalgae, phytoplankton, epiphytic algae), also nutrient limited, which would shade, and eventually exclude $C$. bursa. Hence, resource-limited growth likely represents the most favourable growth condition for the development of C. bursa populations in the Mediterranean littoral.

Acknowledgements. This study was supported by grants (MAR-91-0503 and AMB-94-0746) of the Spanish Interministerial Commission of Science and Technology. B.V. was sup- ported by a fellowship from the Spanish Ministry of Education. We thank Ole Geertz-Hansen for useful suggestions, and providing tissue nutrient analysis and unpublished data. We are specially indebted to $\mathrm{S}$. Enriquez for guidance and help in the laboratory and field work; J. Cebrián, N. Marbá, N. Sant, M. Gallegos, and G. Carreras for field assistance; R. Ventosa for water nutrient analysis; S. Agustí for providing useful information and culture medium; $O$. Delgado for supplying abundant literature; F. Camps (Mas Badía Experimental Research Station) and J. Pascual for providing meteorological and sea temperature data, respectively; and C. Sunyé for hospitality at the study site.

\section{LITERATURE CITED}

Alcoverro T, Duarte CM, Romero J (1995) Annual growth dynamics of Posidonia oceanica: contribution of largescale versus local factors to seasonality. Mar Ecol Prog Ser 120:203-210

Ballesteros E (1989) Production of seaweeds in Northwestern Mediterranean marine communities: its relation with environmental factors. Scient mar 53:357-364

Chapin FS (1988) Ecological aspects of plant mineral nutrition. Adv Min Nutr 3:161-191

Delgado O, Ballesteros E, Vidal M (1994) Seasonal variation in tissue nitrogen and phosphorus of Cystoseira mediterranea Sauvageau (Fucales, Phaeophyceae) in the Northwestern Mediterranean Sea. Botanica mar 37:1-9

Duarte CM (1995) Submerged aquatic vegetation in relation to different nutrient regimes. Ophelia 41:87-112

Estrada M (1979) Observaciones sobre la heterogeneidad del fitoplancton en una zona costera del mar Catalán. Inv Pesq 43(3):637-666

Geertz-Hansen O, Enriquez S, Duarte CM, Agustí A, Vaqué D. Vidondo B (1994) Functional implications of the form of Codium bursa, a balloon-like Mediterranean macroalga Mar Ecol Prog Ser 108:153-160

Grime JP (1974) Vegetation classification by reference to strategies. Nature 250:26-31

Guillard RRL, Ryther JH (1962) Studies of marine planktonic diatoms. I. Cyclotella nana Hustedt and Detonula Confervacea (Cleve) Gran. Can J Microbiol 8:229-239

Hein M, Pedersen MF, Sand-Jensen K (1995) Size-dependent nitrogen uptake in micro- and macroalgae. Mar Ecol Prog Ser 118:247-253

Kemp M. Murray L, McRoy CP (1990) Primary productivity. In: Phillips RC, McRoy CP (eds) Seagrass research methods. UNESCO, Paris, p 83-85

Kirk JTO (1983) Light and photosynthesis in aquatic ecosystems. University Press, Cambridge

Koroleff F (1983) Determination of phosphorus. In: Grasshoff $K$, Egrardt $M$, Kremling $K$ (eds) Methods of seawater analysis, 2nd edn. Verlag-Chemie, Nürnberg, p 125-139

Krom MD, Kress N, Brenner S, Gordon LI (1991) Phosphorus limitation of primary productivity in the Eastern Mediterranean Sea. Limnol Oceanogr 16(3):424-432

Lederman TC. Tett $P$ (1981) Problems in modelling the photosynthesis-light relationship for phytoplankton. Botanica mar 24:125-134

Littler MM (1979) The effects of bottle volume, thallus weight, oxygen saturation levels, and water movement on apparent photosynthetic rates in marine algae. Aquat Bot 7 . $21-34$

Littler MM, Arnold KE (1980) Sources of variability in macroalgal primary productivity: sampling and interpretative problems. Aquat Bot 8:141-156 
Mann KH, Chapman ARO, Gagne JA (1980) Productivity of seaweed: the potential and the reality. In: Falkowski PG (ed) Productivity in the sea. Plenum Press, New York, p 363-380

Paine RT, Slocum CD, Duggins DO (1979) Growth and longevity in the crustose red alga Petrocelis middendorfii. Mar Biol 51:185-192

Pérez M, Duarte CM, Romero J, Sand-Jensen K, Alcoverro T (1994) Growth plasticity in Cymodocea nodosa stands: the importance of nutrient supply. Aquat Bot 47:249-264

Pérez M, Romero J (1992) Photosynthetic response to light of seagrass Cymodocea nodosa and the prediction of its seasonality. Aquat Bot 43:51-62

Pérez M, Romero J, Duarte CM, Sand-Jensen K (1991) Phosphorus limitation of Cymodocea nodosa growth. Mar Biol 109:129-133

Ramus J (1992) Productivity of seaweeds. In: Falkowski PG,

This article was submitted to the editor
Woodhead AD (eds) Primary productivity and biogeochemical cycles in the sea. Plenum Press, New York, p $239-256$

Sokal RR, Rohlf FJ (1981) Biometry. The principles and practice of statistics in biological research, 2nd edn. WH Freeman and Co, New York

Strickland JDH, Parsons TR (1972) A practical handbook of seawater analysis, 2nd edn. Bull Fish Res Bd Can 167

Terrados J, Ros JD (1992) Growth and primary production of Cymodocea nodosa (Ucria) Ascherson in a Mediterranean coastal lagoon: the Mar Menor (SE Spain). Aquat Bot 43: $63-74$

Valiela I (1984) Marine ecological processes. Springer-Verlag, New York

Wehr JD (1989) Experimental tests of nutrient limitation in freshwater picoplankton. Appl environ Microbiol 55: $1605-1611$

Manuscript first received: October 31, 1994

Revised version accepted: February 15, 1995 